\title{
ANALISIS KINERJA MESIN PENGGERAK TRAKTOR PERTANIAN MODEL HST KHS 18 JTDB HASIL PERAKITAN LOKAL DI PT X
}

\author{
Rudi Saputra', Muhammad Fitrah Sunaryo ${ }^{2}$ \\ Program Studi Teknik Mesin, Institut Sains dan Teknologi Nasional ${ }^{12}$ \\ email $^{1}$ : rudisaputra9@yahoo.com
}

\begin{abstract}
A tractor drive engine uses a production diesel engine owned by Company $X$ that is intended to be researched on the effect of working hours that have been used for 3 years which will re-test the performance of the engine using a running test machine. Problems are limited to the analysis of the testing process and calculations that occur in the performance of the tractor drive engine. The analysis was carried out using the theory of fuel motor energy conservation to obtain results in accordance with the specifications regarding the calculation of the test results of the tractor drive engine.The analytical method used to process existing data which includes efficiency, power, torque and generated rotation. The results of the analysis and discussion can prove that the ability of the performance of the agricultural tractor driving machine to the working hours of the machine is still feasible to be used in accordance with the existing specifications so that it can be further developed in the form of mass products to meet agricultural needs.
\end{abstract}

Keywords: Diesel Engine, Fuel Motor, HST KHS 18 JTDB

\section{PENDAHULUAN}

Dengan dikembangkannya pemanfaatan sumber daya alam dengan motor secara langsung mempengaruhi perkembangan dari alat mesin pertanian contohnya mesin pengolahan tanah dahulunya menggunakan tenaga hewan sekarang menggunakan mesin seperti traktor. Dalam perkembangan produksi produk lokal di PT X maka perlu di lakukananalisa kinerja mesin penggerak traktor pertanian tersebut dengan kemampuan kinerjamesin setelah melakukan kerja selama 3 tahun (18.652 jam) terhadap produk tersebut sehingga dapat dikembangkan lebih lanjut dengan perbandingan kapasitas aktual dan teoritis terhadap kinerja mesin tersebut.

\section{TINJAUAN PUSTAKA}

Mesin diesel adalah Sebuah mesin pemicu kompresi, dimana bahan bakardinyalakan oleh suhu tinggi gas yang dikompresi. Ketika udara dikompresi suhunya akan meningkat, mesin diesel menggunakan sifat ini untuk proses pembakaran. Udara di hisap ke dalam ruang bakar mesin diesel dan dikompresi oleh pistonyang merapat, jauh lebih tinggi dari rasio compresi dari mesin bensin. Beberapa saat sebelum piston pada posisi Titik Mati Atas (TMA) atau BTDC (Before Top Dead Center), bahan bakar diesel disuntikkan keruang bakar dalam tekanan tinggi melalui nozzle supaya bercampur dengan udara panas yang bertekanan tinggi.Hasil pencampuran ini menyala dan terbakar dengan cepat.Penyemprotan bahan bakar ke ruang bakar mulai dilakukan saat pistonmendekati (sangat dekat) TMA untuk menghindari detonasi.Ledakan tertutup ini menyebabkan gas dalam ruang pembakaran mengembang dengan cepat, mendorong piston ke bawah dan menghasilkan tenaga linear.Batang penghubung (connecting rod) menyalurkan gerakan ini ke crankshaft dan oleh crankshaft tenaga linear diubah menjadi tenaga putar.Tenaga putar pada ujung poros crankshaft dimanfaatkan untuk berbagai keperluan.

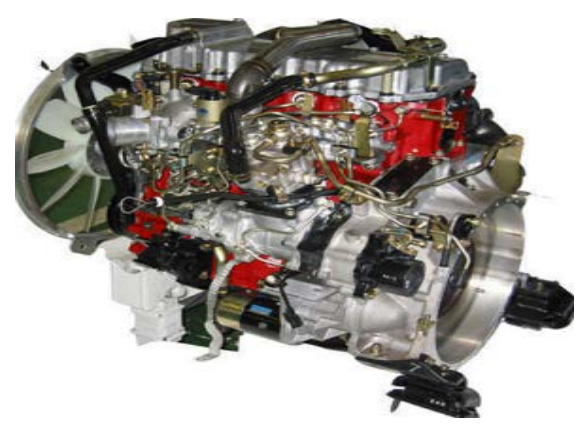

\section{Gambar 1.Motor Bakar Diesel}

Motor empat langkah adalah motor yang menyelesaikan satu siklus pembakaran dalam empat langkah torak atau dua kali putaran poros engkol, jadi dal satu siklus kerja telah mengadakan 
prosespengisian,kompresi dan penyalaan,ekspansi serta pembuangan.Dibandingkan dengan motor 2 tak, motor 4 tak lebih sulit dalam perawatan karena banyak komponen-komponen pada bagian mesinnya. Pada motor empat tak titik paling atas yang mampu dicapai oleh gerakan torak disebut titik mati atas(TMA), sedangkan titik terendah yang mampu dicapai torak pada silinder disebut titik mati bawah(TMB). Dengan asumsi bahwa katup masuk dan katup buang terbuka tepat pada waktu piston berada pada TMA dan TMB, maka siklus motor 4 (empat) langkah dapat diterangkan sebagai berikut:
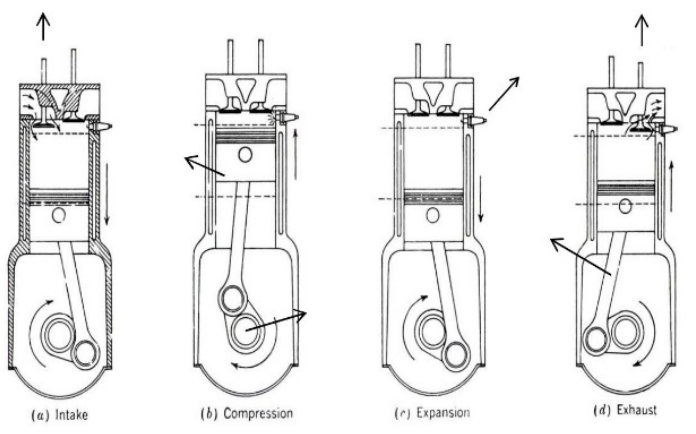

Gambar 2. Siklus Motor Bakar 4 Langkah

\section{Siklus Diesel}

Siklus diesel yang merupakan siklus dari mesin penyalaan kompresi (compression-ignition) ditemukan oleh Rudolph Diesel pada tahun 1890. Perbedaan mesin diesel dengan mesin otto terletak pada permulaan pembakarannya. Pada motor bensin, campuran udara-bensin dikompresi dibawah temperatur pembakaran bahan bakar dan proses pembakarannya dimulai dari percikan bungaapi pada busi. Sedangkan pada mesin diesel, udara murni diisap dan dikompresi diatas temperatur pembakaran bahan bakar. Jadi, pada mesin diesel tidak terdapat karburator dan busi tetapi diganti oleh injektor bahan bakar.

Pada mesin bensin, yang dikompresi adalah campuran udara-bensin dan besarnya perbandingan kompresi dibatasi oleh temperatur terbakarnya bensin. Pada mesin diesel, yang dikompresi adalah udaranya saja sehingga mesin diesel dapat didesain pada perbandingan kompresi yang tinggi, antara 12 sampai 24. Proses injeksi bahan bakar dimulai pada saat piston hampir mencapai titik mati atas dan masih berlangsung beberapa saat setelah piston mencapai TMA. Oleh karena itu, proses pembakaran pada mesin diesel terjadi pada interval waktu yang relative panjang dibanding dengan mesin bensin. Dengan interval waktu pembakaran yang relatif panjang tersebut, maka proses pemasukan panas didekati (approximated) sebagai proses tekanan konstan, sedangkan tiga proses lainnya sama dengan mesin bensin.
Perbandingan efesiensi antara mesin diesel dengan mesin bensin adalah terletak pada nilai suku yang ada didalam kurung dimana nilainya selalu lebih besar dari satu. Oleh karena itu, dapat disimpulkan bahwa jika perbandingan kompresi antara mesin bensin dan mesin diesel sama maka efisiensi mesin bensin lebih tinggi dibanding mesin diesel. Namun, harus diingat bahwa mesin diesel dapat dioprasikan pada perbandingan kompresi yang lebih tinggi tanpa khawatir akan terjadi pembakaran sebelum waktunya sehingga efisiensi mesin diesel lebih tinggi dari mesin otto. Selain itu, proses pembakaran mesin diesel lebih sempurna karena mesin diesel beroprasi pada putaran lebih rendah maka mesin diesel menjadi pilihan untuk keperluan mesin dengan power besar seperti mesin lokomotif, kapal laut, truk, dan lain lain.

Motor diesel 4 langkah adalah suatu motor yang tiap satu silindernya untuk mendapatkan satu kali pembakaran membutuhkan empat kali gerakan piston yaitu dua kali bergerak ke bawah atau dua kali putaran poros engkol.Prinsip kerja motor 4 langkah dapat dilihat pada Gambar 3, berikut.

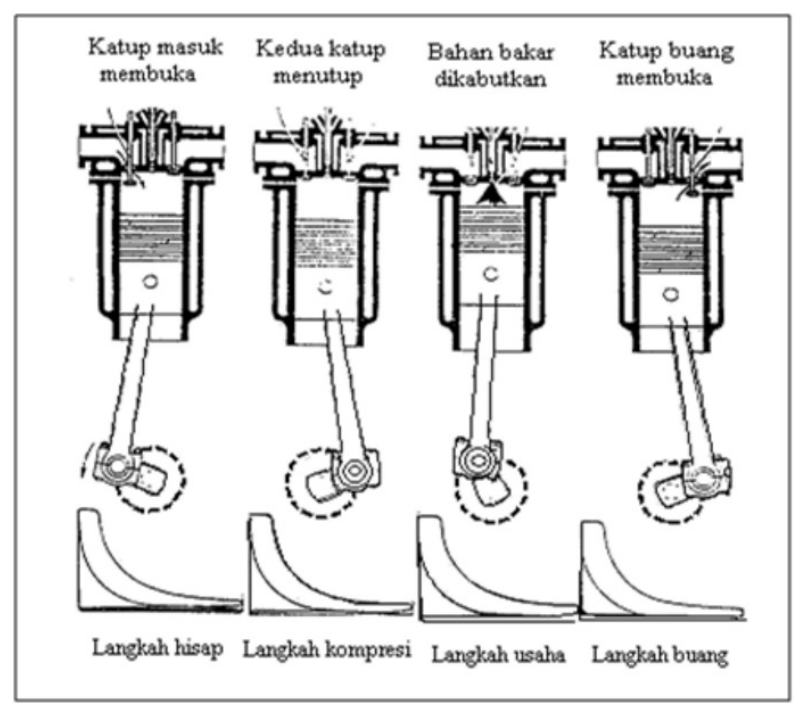

Gambar 3 Proses Kerja Motor Diesel 4 Langkah

Pada motor diesel 4-langkah terdapat langkahlangkah:
1. langkah hisap (Suction - Sroke)
2. langkah kompresi (Compression - Stroke)
3. langkah usaha (Power - Stroke)
4. langkah buang (Exhaust - Stroke)

\section{Efesiensi}

Efisiensi mesin mengacu pada kemampuan mesin untuk mengubah energi yang tersedia dari bahan bakar menjadi tenaga gerak yang berguna.Mesin bensin modern beroperasi pada ratarata sekitar 20 sampai 30 persen efisiensi.Sisa 70 sampai 80 persen energi dari bensin dikeluarkan dari 
mesin baik sebagai panas, energi suara mekanik, atau gesekan.Pada saat tidak sedang berjalan, efisiensi mesin adalah nol karena mesin tidak menggerakkan kendaraan dan hanya mengoperasikan aksesoris, seperti pompa air dan generator.Dibanding mesin bensin, mesin diesel dianggap lebih efisien.Mesin diesel menggunakan kompresi tinggi pada silinder untuk menyalakan bahan bakar.

Kompresi lebih tinggi ini membuat mesin diesel memiliki efisiensi sekitar 40 persen.Efisiensi ini lazimnya hanya tercapai pada mesin diesel jenis injeksi langsung.

Rasio kompresi mesin juga akan mempengaruhi efisiensi mesin. Hal ini disebabkan, sebagian, karena kemampuan mesin untuk mengubah panas dari proses pembakaran untuk menghasilkan energi. Maka dari itu di dapatkan cara menghitung efesiensi pada Running Test Machine dengan melakukan perbandingan Antara putaran tanpa beban dengan menggunakan beban dengan persamaan:

1. $\alpha$ Effeciency :

$(\mathrm{N} 2 / \mathrm{N} 1)$ X $100 \%=(3014 / 3024) \times 100 \%$

$=0,99$ X $100 \%=99 \%$

2. $\beta$ Effeciency :

$(\mathrm{N} 4$ / N3) X 100\% = (2546/ 3090$)$ X $100 \%$

$=0,82 \times 100 \%=82 \%$

\section{Daya}

Daya didefinisikan sebagai laju aliran kerja dan sama dengan perkalian antara gaya linear dengan torsi. Definisi ilmiah dari horsepower adalah jumlah energy yang dibutuhkan untuk mengangkat benda seberat satuan berat setinggi satuan tinggi dalam waktu satuan detik. Untuk pengukuran daya, yang diukur adalah torsi yang dihasilkan oleh roda, yang kemudian menjadi acuan dalam perhitungan daya, selanjutnya untuk mengetahui putaran mesin (rpm) menggunakan tachometer yang sudah ada didalam dynamometer tersebutdengan cara mengkalibrasi antara perputaran shaft dengan perputaran roller, selain itu dapat juga menggunakan tachometer manual. Hubungan rumus daya dengan torsi adalah dengan fungsi persamaan :

$$
\mathrm{P}=\frac{2 \times \pi \times n \times T}{60 \times 1000}(k W)
$$

Dimana :

$\mathrm{P}=$ Daya Output/daya poros berguna $(\mathrm{kW})$

$\mathrm{n}=$ Putaran (rpm)

$\mathrm{T}=$ Torsi / Momen putar/puntir (N.m)

$60=1$ menit

$1000=$ Watt - kiloWatt

\section{Torsi}

Definisi dari torsi atau momen inersia (rotational force) adalah perkalian antara gaya tangensial dengan jarak lengan berputar. Torsi maksimum biasanya digunakan saat kendaraan mau bergerak dan sedang membawa beban berat, biasa disebut akselarasi/tarikan awal. Analoginya, waktu kita mendorong motor pada saat keadaan diam, sesaat sebelum bergerak akan terasa berat sekali, maka kaki butuh menjejak kuat dan mendorong sekuatnya agar motor bergerak, saat motor sudah melaju/ bergerak maka hanya perlu sedikit torsi, tapi diperlukan lebih banyak daya untuk mendapatkan dan menjaga kecepatan yang tinggi. untuk mendefinisikan torsi pada dynamometer adalah dengan persamaan berikut :

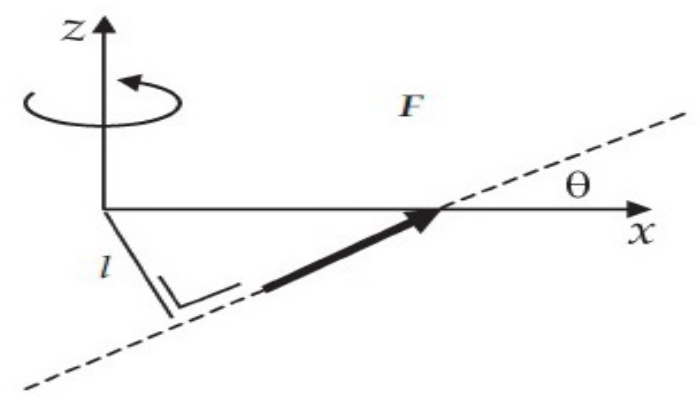

Gambar 4 Perhitungan Torsi Dengan Jarak Lengan Berputar

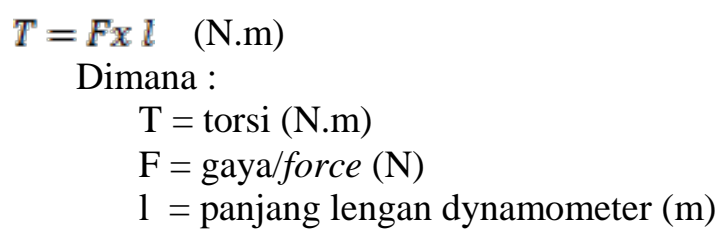

\section{METODE PENELITIAN}

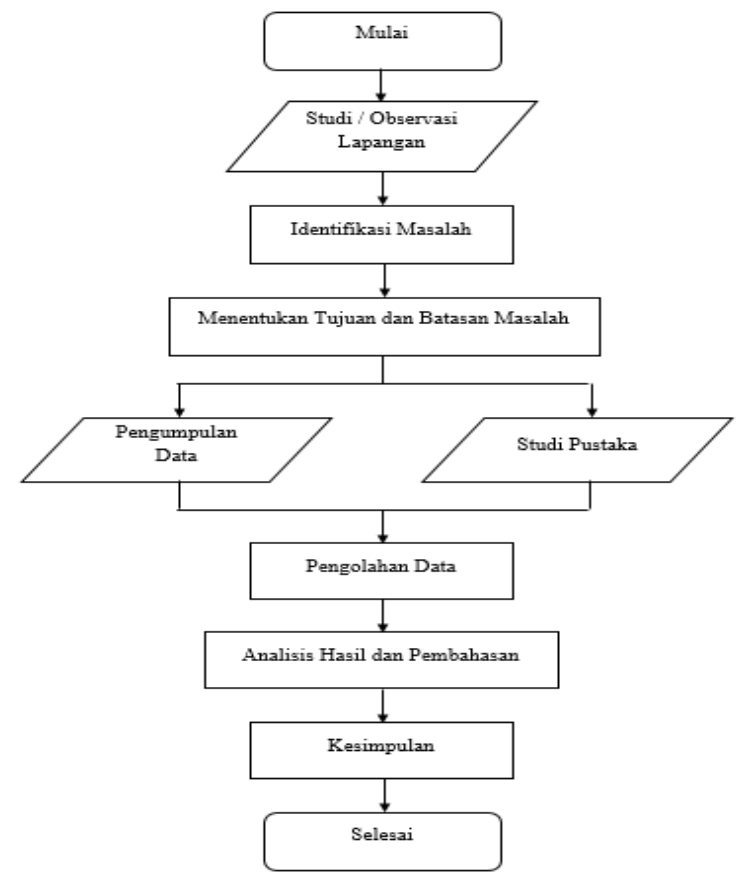

Gambar 5. Diaaram alir penelitian 


\section{Prosedur Pengumpulan Data}

Kegiatan persiapan sebelum melakukan pengujian dimaksudkan untuk memperoleh data terukur yang lebih akurat dan presisi. Persiapanpersiapan tersebut mencakup beberapa pemeriksaan diantaranya:

1. Menempatkan mesin penggerak traktor HST model KHS 18 JTDB pada JIG running test machine yang akan diuji hasil kinerja mesin yang terlihat pada gambar 6 .

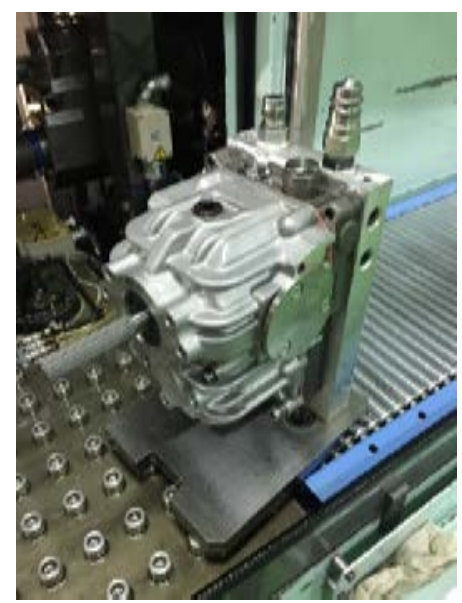

Gambar 6 Pemasangan JIG Running Test Machine pada HST KHS 18 JTDB

2. Setelah mesin penggerak dipasangkan kepada JIG Running Test Machine, selanjutnya menempatkan pemasangan jig mesin pada Running Test Machine yang terdapat adapter shaft dan selang oli untuk dilakukan uji coba guna memperolah hasil/data.

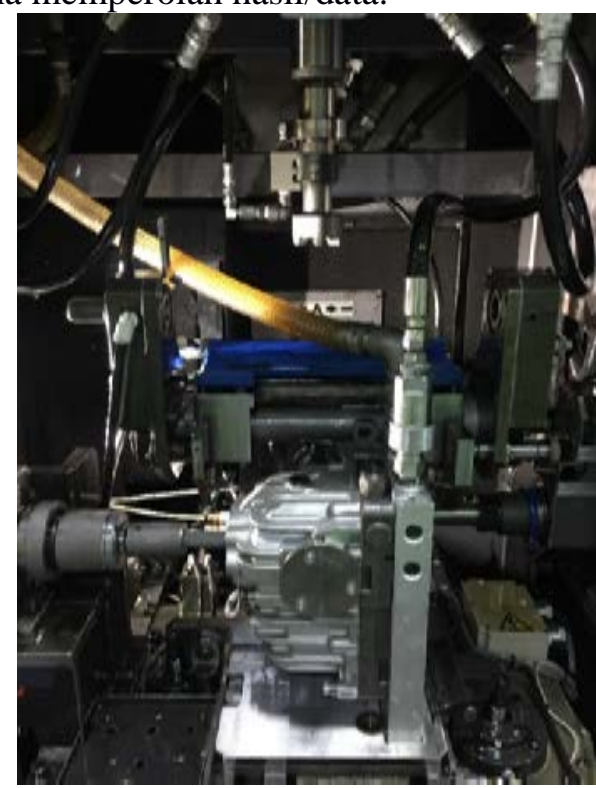

Gambar 7 Persiapan Uji Coba Running Test Machine

3. Scan barcode sesuai dengan program yang akan di jalankan pada running test machine.
4. Menjalankan running test machine dengan menekan tombol start pada mesin tersebut.

5. Setelah pengujian terhadap HST baru selesai, selanjutnya melakukan pengujian terhadap HST yang sudah di pakai selama 3 tahun (18.652 jam).

6. Kemudian hasil pengujian akan diambil datanya dengan menggunakan software N93 yang terdapat pada aplikasi laptop input data sebagai penghubung untuk mengambil data hasil pengujian tersebut.

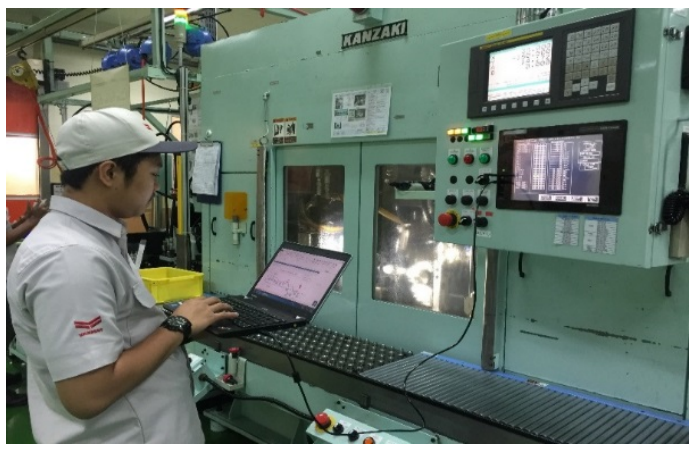

Gambar 8 Proses Pengambilan Data Pada Running Test Machine

7. Setelah pengujian dengan running test machine selesai, maka selanjutnya adalah melakukan analisa kinerja mesin secara teoritis dan aktual dengan membandingkan antara HST baru dengan setelah pemakaian 3 tahun.

\section{Spesifikasi Data Mesin}

Tabel Spesifikasi Data Mesin

\begin{tabular}{|c|c|c|c|}
\hline No & Spesifiksasi & Maximum & Minimum \\
\hline 1. & $\alpha$ Effeciency [96] & 97 & 92 \\
\hline 2. & $\beta$ Effeciency [\%] & 87 & 76.5 \\
\hline 3. & $P 1$ on $[M P a]$ & 0.79 & 0.49 \\
\hline 4. & $\alpha$ Side torque $[\mathrm{N}-\mathrm{m}]$ & 25.10 & 13.10 \\
\hline 5. & $\beta$ Side torque $[\mathrm{N} \cdot \mathrm{m}]$ & 25.10 & 13.10 \\
\hline 6. & Temperature Oil $\left[{ }^{\circ} \mathrm{C}\right]$ & so & 25 \\
\hline 7. & $N 1[m ; n-1]$ RPM & 3450 & 3150 \\
\hline 8. & $N 2[m i n-1] R P M$ & 3350 & 2830 \\
\hline 9. & N $3[m$ i $n-1] R P M$ & 3240 & 2940 \\
\hline 10. & $\mathrm{~N} 4[\mathrm{~m} ; \mathrm{n}-1] \mathrm{RPM}$ & 2850 & 2200 \\
\hline 11. & Input rotation speed $[\mathrm{mi} \mathrm{n}-1]$ RPM & 3250 & 3150 \\
\hline 12. & a Load pressure $[M P$ a] & 10 & 0.50 \\
\hline 13 & $\beta$ Load pressure $[M P$ a ] & 10 & 0.50 \\
\hline
\end{tabular}


Tabel Data Hasil Pengujian Mesin HST Pada Perakitan Awal

\begin{tabular}{|c|c|c|c|c|}
\hline & Specification & & Speed I & \\
\hline No & Subject ( Standard Tolerance ) & 3150 & 3200 & 3250 \\
\hline 1 & $\alpha$ Effeciency 【\%】(92-97) & 93,2 & 92,7 & 93,0 \\
\hline 2 & $\beta$ Effeciency【\%】(76.5-87) & 82,1 & 81,9 & 82,1 \\
\hline 3 & $P 1$ on $[\mathrm{MPa}$ 】 $(0.49-0.79)$ & 0,72 & 0,70 & 0,73 \\
\hline 4 & $\alpha$ Side torque $[\mathrm{N} \cdot \mathrm{m}](13.10-25.10)$ & 18,43 & 18,13 & 17,52 \\
\hline 5 & $\beta$ Side torque $[\mathrm{N} \cdot \mathrm{m} \rrbracket(13.10-25.10)$ & 15,97 & 16,09 & 16,39 \\
\hline 6 & Temperature Oil 【 $\left[{ }^{\circ} \mathrm{C} 】(25-50)\right.$ & 37,5 & 37,5 & 37,7 \\
\hline 7 & N 1 【m i n-1】 (3150-3450) & 3357 & 3377 & 3371 \\
\hline 8 & $\mathrm{~N} 2\lfloor\mathrm{~m} i \mathrm{n}-1 \rrbracket(2830-3350)$ & 3132 & 3132 & 3136 \\
\hline 9 & N 3 【m i n-1】 (2940-3240) & 3032 & 3020 & 3031 \\
\hline 10 & N 4 [m i n-1] (2200-2850) & 2492 & 2475 & 2489 \\
\hline
\end{tabular}

\section{Perhitungan Daya Mesin HST KHS 18 JTDB Perakitan Awal}

Perhitungan Daya berdasarkan hasil pengujian pada perakitan awal pada rate input speed $3150 \mathrm{rpm}$ dengan putaran yang dihasilkan 3357 rpm pada HST KHS 18 JTDB untuk putaran maju :

$$
\begin{aligned}
& \mathrm{HP}=\frac{2 \times \pi \times n \times T}{60 \times 1000}(k W) \\
& \mathrm{HP}=\frac{2 \times 3.14 \times 3150 \times 18.43}{60}(\mathrm{~kW}) \\
& \mathrm{HP}=\frac{364582.261000}{60000}(\mathrm{~kW}) \\
& \mathrm{HP}=6.07(\mathrm{~kW})
\end{aligned}
$$

\section{Dimana :}

$\mathrm{HP}=$ Daya Output/daya poros berguna $(\mathrm{kW})$

$\mathrm{n}=$ Putaran (rpm)

$\mathrm{T}=$ Torsi (N.m)

$60=1$ menit

$1000=$ Watt - kiloWatt

\section{Perhitungan Efesiensi Pada mesin HST KHS 18} JTDB Perakitan Awal

a Effeciency ( Putaran Maju ) :

$(\mathrm{N} 2 / \mathrm{N} 1) \times 100 \%=(3132 / 3357) \times 100 \%=0,93$

$\mathrm{X} 100 \%=93 \%$

$\beta$ Effeciency (Putaran Mundur ) :

$(\mathrm{N} 4 / \mathrm{N} 3) \mathrm{X} 100 \%=(2492 / 3020) \times 100 \%=$

0,82 X $100 \%=82 \%$

Dimana :

N1 =Puataran Maju Tanpa Beban (rpm)

N2 = Putaran Maju Dengan Beban (rpm)

N3 =Putaran Mundur Tanpa Beban (rpm)

\begin{tabular}{|c|c|c|c|c|}
\hline \multirow[b]{2}{*}{ No } & \multirow{2}{*}{$\begin{array}{c}\text { Specification } \\
\text { Subject ( Standard Tolerance ) }\end{array}$} & \multicolumn{3}{|c|}{ Input Speed ( rpm ) } \\
\hline & & 3150 & 3200 & 3250 \\
\hline 1 & $\alpha$ Effeciency【\%】(92-97) & 93,4 & 93,45 & 93,5 \\
\hline 2 & $\beta$ Effeciency【\%】(76.5-87) & 82,3 & 82,0 & 82,2 \\
\hline 3 & $P 1 \circ n 【 M P a 】(0.49-0.79)$ & 0,62 & 0,68 & 0,63 \\
\hline 4 & $\alpha$ Side torque $[N \cdot m 】(13.10-25.10)$ & 17,82 & 17,27 & 18,07 \\
\hline 5 & $\beta$ Side torque $[N \cdot \mathrm{m}](13.10-25.10)$ & 15,53 & 15,32 & 15,19 \\
\hline 6 & Temperature Oil【 【 ${ }^{\circ} \mathrm{C} 】(25-50)$ & 40,0 & 38,7 & 41,8 \\
\hline 7 & N1【m i n-1】(3150-3450) & 3224 & 3208 & 3240 \\
\hline 8 & $N 2\lfloor m$ i $n-1 】(2830-3350)$ & 3014 & 2998 & 3031 \\
\hline 9 & N $3[m i n-1](2940-3240)$ & 3090 & 3087 & 3072 \\
\hline 10 & N4【m i n-1】(2200-2850) & 2546 & 2532 & 2526 \\
\hline 12 & $\alpha$ Load pressure 【MP $\mathrm{P} 】(0.50-10)$ & 4,57 & 4,70 & 4,58 \\
\hline 13 & $\beta$ Load pressure 【M $\mathrm{Pa} \backslash(0.50-10)$ & 4,69 & 4,73 & 4,68 \\
\hline
\end{tabular}

N4= Puataran Mundur Dengan Beban (rpm)
Tabel Data Hasil Pengujian Mesin HST setelah 3 tahun (18.652 jam )

Perhitungan Daya Mesin HST KHS 18 JTDB setelah Pemakaian 3 tahun.

Perhitungan Daya berdasarkan hasil pengujian pada pengujian setelah pemakaian 3 tahun (18.652 jam) dengan putaran yang dihasilkan 3224 rpm pada HST KHS 18 JTDB pada putaran maju :

$$
\begin{aligned}
& \mathrm{HP}=\frac{2 \times \pi \times n \times T}{60 \times 1000}(k W) \\
& \mathrm{HP}=\frac{2 \times 3.14 \times 3150 \times 17.82}{660 \times 1000}(k W) \\
& \mathrm{HP}=\frac{360796.55}{60000}(\mathrm{~kW}) \\
& \mathrm{HP}=5.87(k W)
\end{aligned}
$$

Dimana :

$\mathrm{HP}=$ Daya Output/daya poros berguna $(\mathrm{kW})$

$\mathrm{N}=$ Putaran (rpm)

$\mathrm{T}=$ Torsi (N.m)

$60=1$ menit

$1000=$ Watt - kiloWatt

Perhitungan Efesiensi Mesin HST KHS 18 JTDB setelah Pemakaian 3 tahun

$\alpha$ Effeciency ( Putaran Maju ) :

$(\mathrm{N} 2 / \mathrm{N} 1) \times 100 \%=(3132 / 3357) \times 100 \%=0,93$

$\mathrm{X} 100 \%=93 \%$

$\beta$ Effeciency (Putaran Mundur ) :

$(\mathrm{N} 4 / \mathrm{N} 3) \times 100 \%=(2492 / 3020) \times 100 \%=$

$0,82 \times 100 \%=82 \%$

Dimana :

N1 =Puataran Maju Tanpa Beban (rpm)

N2 = Putaran Maju Dengan Beban (rpm)

N3 =Putaran Mundur Tanpa Beban (rpm)

N4 = Puataran Mundur Dengan Beban (rpm) 


\section{ANALISIS HASIL DAN PEMBAHASAN Hasil Perbandingan Pada Daya dan Torsi Pada Putaran Maju}

Hasil pengujian antara perakitan awal dengan perakitan baru dengan input speed 3150 3250 rpm pada putaran maju menghasilkan Daya dan Torsi yang mengalami penurunan dan penaikan setelah pemakaian selama 3 tahun (18.652 jam), namun masih dalam spesifikasi yang di izinkan.

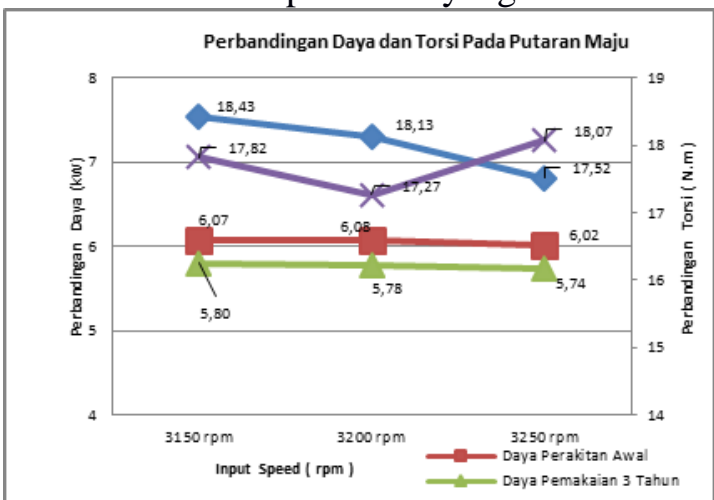

Gambar 12 Grafik Perbandingan Daya dan Torsi pada putaran maju antara Perakitan Awal Dengan Pemakaian Selama 3 Tahun

\section{Hasil Perbandingan Pada Daya dan Torsi Pada Putaran Mundur}

Hasil pengujian antara perakitan awal dengan perakitan baru dengan input speed 3150 3250 rpm pada putaran mundur menghasilkan Daya dan Torsi yang mengalami penaikan dan penurunan setelah pemakaian selama 3 tahun (18.652 jam), namun masih dalam spesifikasi yang di izinkan.

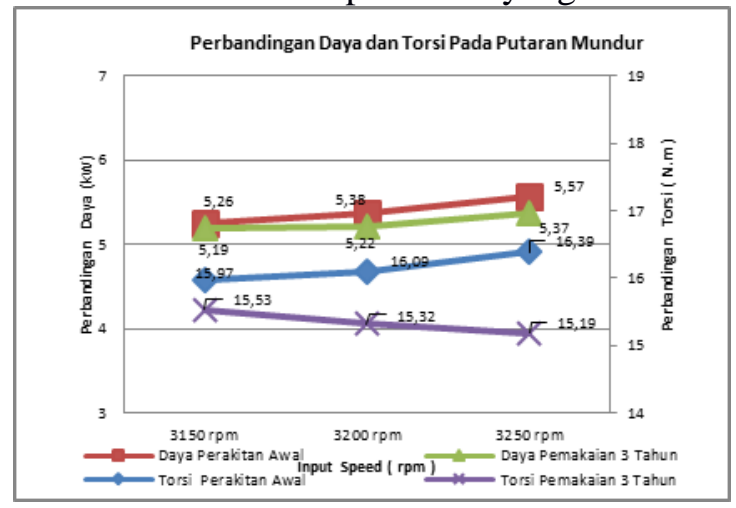

Gambar 13 Grafik Perbandingan Daya dan Torsi pada putaran Mundur antara Perakitan Awal Dengan Pemakaian Selama 3 Tahun.

\section{Perbandingan Efesiensi dan Torsi pada Putaran Maju}

Hasil pengujian pada efesiensi dengan torsi pada putaran maju dengan input speed 3150 -3250 rpm adalah terjadinya penaikan dan penurunan pada efesiensi dan torsi, artinya torsi tersebut berbanding terbalik dengan hasil efesiensi, namun hasil tersebut masih dalam spesifikasi yang di izinkan dimana efesiensi pada ( $76.5 \%$ - $87 \%$ ), dan Torsi pada ( 13.10 N.m - 25.10 N.m ).

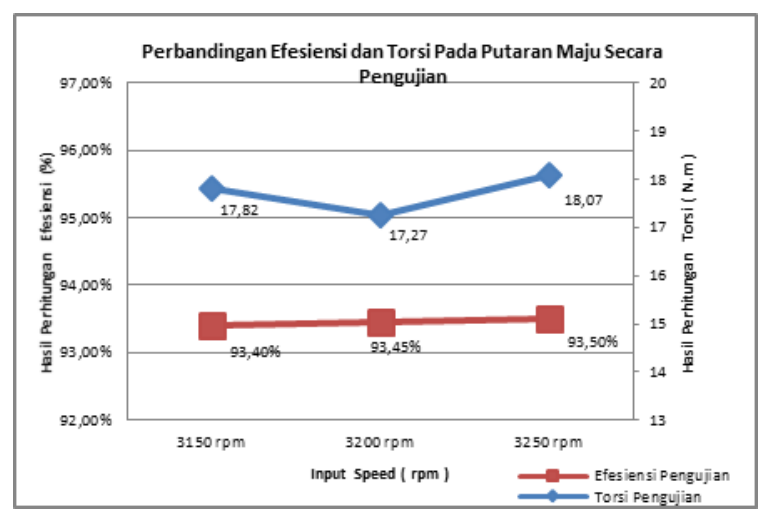

Gambar 14 Grafik Perbandingan Efesiensi dan Torsi pada putaran Maju secara pengujian Pemakaian Selama 3 Tahun.

\section{Perbandingan Efesiensi dan Torsi pada Putaran Mundur}

Hasil pengujian dan teoritis efesiensi dengan torsi pada putaran mundur dengan input speed 3150 3250 rpm adalah terjadinya kenaikan dan penurusan pada efesiensi dan torsi tersebut, namun hasil tersebut masih dalam spesifikasi yang di izinkan, dimana efesiensi pada ( $76.5 \%-87 \%$ ), dan Torsi pada ( 13.10 N.m - 25.10 N.m).

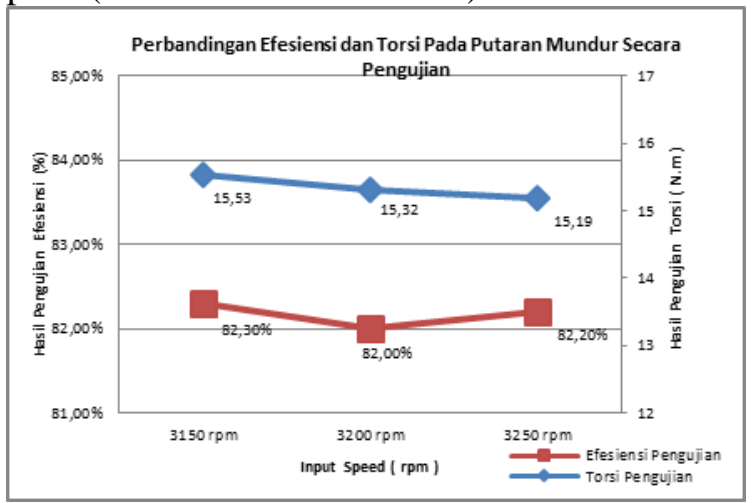

Gambar 15 Grafik Perbandingan Efesiensi dan Torsi pada putaran Maju secara pengujian Pemakaian Selama 3 Tahun.

\section{Efesiensi pada Putaran Maju (Forward Effeciency)}

Hasil pengujian dan teoritis efesiensi putaran maju pada analisa kinerja mesin transmisi 18 CC setelah pemakaian selama 3 tahun pada input speed $3150 \mathrm{rpm}$ sampai dengan $3250 \mathrm{rpm}$ adalah antara 93,4 \% - 93,5 \%, dengan ini hasilnya masih sesuai dengan spesifikasi yang sudah ditentukan di kisaran antara $92 \%$ N.m sampai $97 \%$ N.m. 


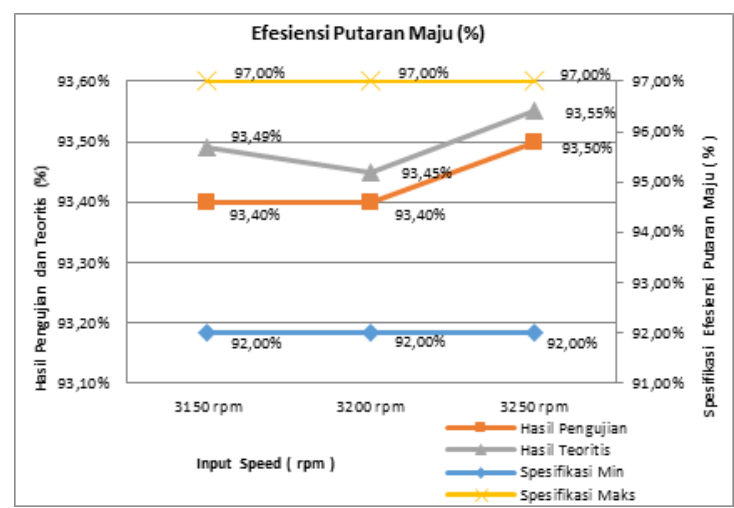

Gambar 16 Grafik Hasil Efesiensi Pada Putaran Maju Secara Pengujian Dan Teoritis

\section{Efesiensi pada Putaran Mundur ( Reverse Effeciency)}

Hasil pengujian dan teoritis efesiensi putaran mundur pada analisa kinerja mesin transmisi 18 CC setelah pemakaian selama 3 tahun pada input speed $3150 \mathrm{rpm}$ sampai dengan $3250 \mathrm{rpm}$ adalah antara 82 $\%$ - 82,39 \%, dengan ini hasilnya masih sesuai dengan spesifikasi yang sudah ditentukan di kisaran antara 76,5 \% N.m sampai 87 \% N.m.

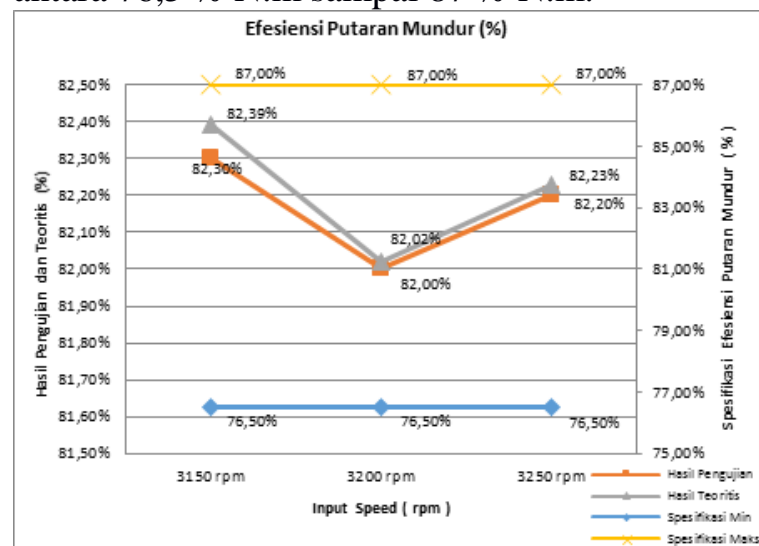

Gambar 17 Grafik Hasil Efesiensi Pada Putaran Mundur Secara Pengujian Dan Teoritis

\section{Torsi pada Putaran Maju (forward torque )}

Hasil pengujian dan teoritis Torsi putaran maju pada analisa kinerja mesin transmisi 18 CC setelah pemakaian selama 3 tahun pada input speed 3150 rpm sampai dengan $3250 \mathrm{rpm}$ adalah antara 17.27 N.m - 18.07 N.m, dengan ini hasilnya masih sesuai dengan spek yang sudah ditentukan di kisaran min 13.10 N.m sampai 25.10 N.m pada efesiensi maju $93 \%$.

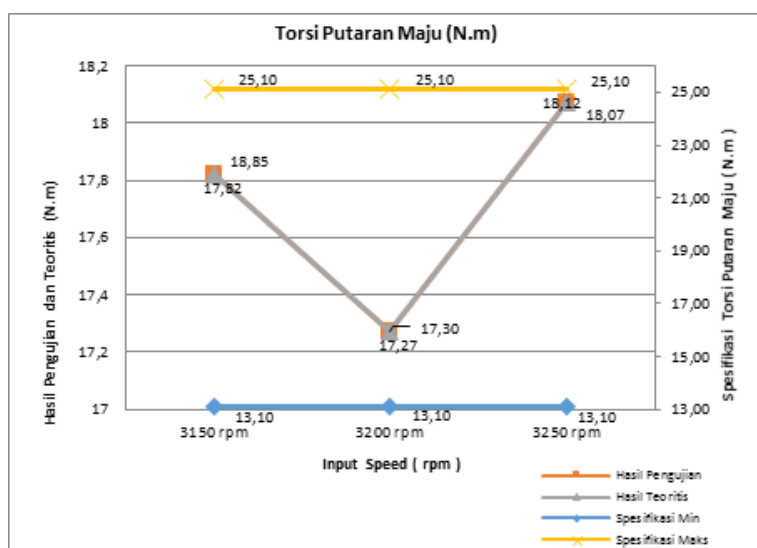

Gambar 18 Grafik Torsi Mesin Pada Putaran Maju Secara Pengujian Dan Teoritis

\section{Torsi Putaran Mundur(Reverse Torque )}

Hasil pengujian dan teoritis Torsi putaran mundur pada analisa kinerja mesin transmisi 18 CC setelah pemakaian selama 3 tahun pada input speed $3150 \mathrm{rpm}$ sampai dengan $3250 \mathrm{rpm}$ adalah antara 18.02 N.m - 18.91 N.m , dengan ini hasil masih sesuai dengan spesifikasi yang sudah ditentukan di kisaran antara 13.10 N.m sampai 25.10 N.m pada efesiensi mundur $82 \%$.

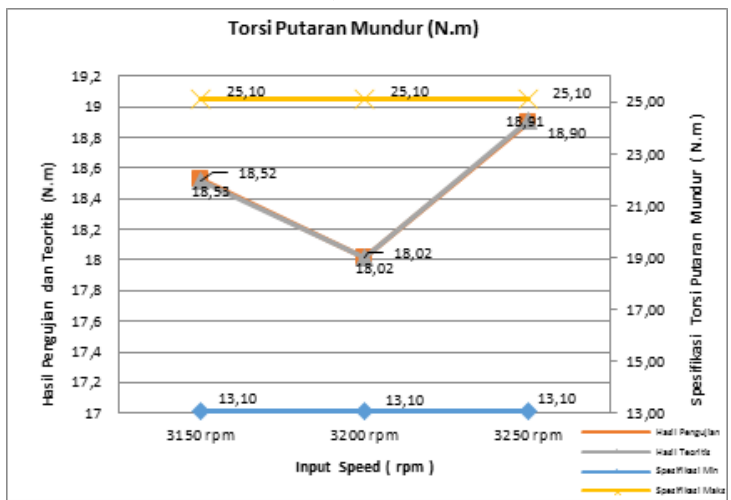

Gambar 19 Grafik Torsi Mesin Pada Putaran Mundur Secara Pengujian Dan Teoritis

\section{Putaran Yang Dihasilkan Pada Posisi Maju (Forward Rotation)}

Hasil pengujian dan teoritis kecepatan putaran maju pada analisa kinerja mesin transmisi 18 CC setelah pemakaian selama 3 tahun pada input speed $3150 \mathrm{rpm}$ sampai dengan $3250 \mathrm{rpm}$ adalah antara 3199.25 - $3249.44 \mathrm{rpm}$, dengan ini hasilnya masih sesuai dengan spesifikasi yang sudah ditentukan di kisaran antara 3150 rpm sampai 3450 rpm pada efesiensi maju $93 \%$. 


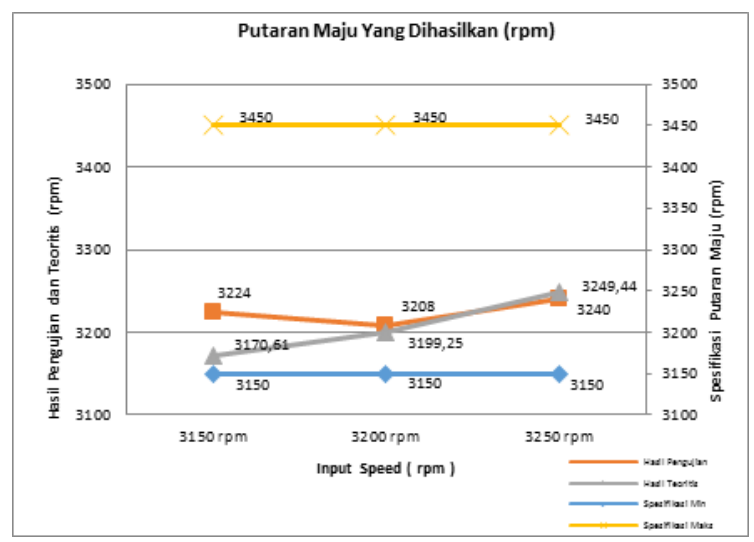

Gambar 20 Grafik Hasil Putaran Yang Dihasilkan

Pada Posisi Maju Mesin Secara Pengujian dan Teoritis

\section{Putaran Yang Dihasilan Pada Posisi Mundur ( Reverse Rotation )}

Hasil pengujian dan teoritis kecepatan putaran mundur pada analisa kinerja mesin transmisi 18 CC setelah pemakaian selama 3 tahun pada input speed $3150 \mathrm{rpm}$ sampai dengan $3250 \mathrm{rpm}$ adalah antara $2998 \mathrm{rpm}$ - 3249,52 rpm , dengan ini hasil masih sesuai dengan spesifikasi yang sudah ditentukan di kisaran antara 2830 rpm sampai 3350 rpm pada efesiensi mundur $82 \%$.

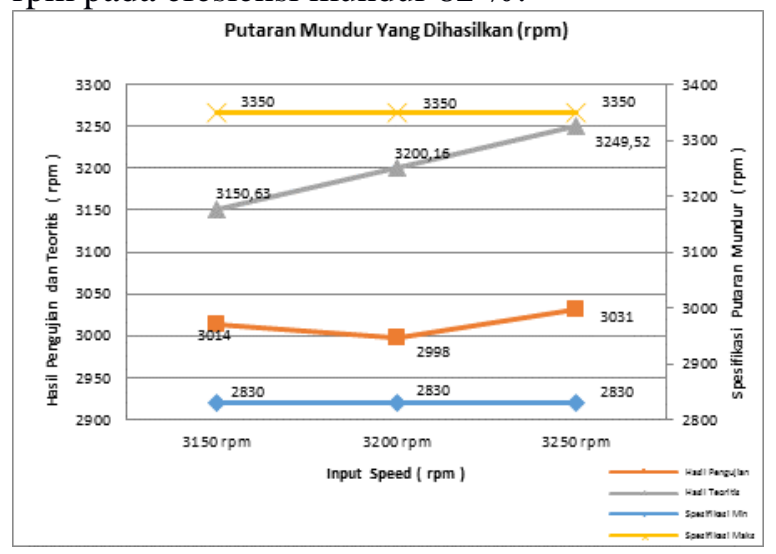

Gambar 21 Grafik Hasil Putaran yang Dihasilkan pada Posisi Mundur Secara Pengujian dan Teoritis

\section{KESIMPULAN}

Berdasarkan hasil analisis dan pembahasan pada bab 4 mengenai perbandingan antara hasil pengujian dengan hasil teoritis terhadap kinerja mesin penggerak traktor HST KHS 18 JTDB, maka dihasilkan data data sebagai berikut :

1. Efesiensi untuk input speed $3150 \mathrm{rpm}$ sampai 3250 rpm pada putaran maju dengan putaran mundur menghasilkan hasil yang sesuai dengan standar yang ada pada spesisifkasi running test mesin, yaitu dengan adanya perbedaan $\pm 0,1 \%$ antara pengujian dengan teoritis.
2. Torsi untuk input speed $3150 \mathrm{rpm}$ sampai 3250 rpm pada putaran maju dengan putaran mundur menghasilkan hasil yang sesuai dengan standar yang ada pada spesisifkasi running test mesin, yaitu dengan adanya perbedaan $\pm 0,1 \%$ antara pengujian dengan teoritis.

3. Putaran yang dihasilkan untuk input speed 3150 rpm sampai $3250 \mathrm{rpm}$ pada putaran maju dengan putaran mundur menghasilkan hasil yang sesuai dengan standar yang ada pada spesisifkasi running test mesin, yaitu dengan adanya perbedaan $\pm 0,2 \%$ antara pengujian dengan teoritis.

4. Daya yang dihasilkan untuk input speed 3150 rpm sampai $3250 \mathrm{rpm}$ pada putaran maju dengan putaran mundur menghasilkan hasil yang sesuai dengan standar yang ada pada spesisifkasi running test mesin, yaitu dengan adanya perbedaan $\pm 0,1 \%$ antara pengujian dengan teoritis.

Dari hasil Kesimpulan di atas melalui analis yang dilakukan, kondisi mesin masih berada dalam standar spesifikasi yang ada, artinya mesin penggerak traktor HST KHS 18 JTDB terhadap pemakaian jam kerja selama 3 tahun yaitu 18.652 jam masih masih layak untuk dipergunakan sehingga tingkat kemampuan kinerja mesin traktor pertanian tersebut kedepannya dapat dikembangkan lebih lanjut dalam bentuk produk massal untuk memenuhi kebutuhan pertanian, hal ini terjadi dikarenakan perawatan mesin yang baik pada saat 3 tahun pemakaian terhadap jam kerja dan penggunaan mesin tersebut sesuai dengan kebutuhan atau kinerja yang sanggup di lakukan oleh mesin tersebut dalam industri pertanian.

\section{DAFTAR PUSTAKA}

J. Trommel Mans. (1991). Mesin Diesel, Jakarta : Penerbit PT Rosda Jayaputra.

Daryanto.(2004). Motor Diesel Pada Mobil.Yrama Widya, Bandung.

Murni, Berkah Fajar, Tony Suryo. PENGARUH TEMPERATUR SOLAR TERHADAP PERFORMA MESIN DIESEL DIRECT INJECTION PUTARAN KONSTAN. Jurusan Diploma Teknik Mesin Universitas Diponegoro. Semarang.

Dicky Yoko Exoryanto, Bambang Sudarmanta. Studi eksperimen unjuk kerja mesin diesel menggunakan sistem duel fuel solar gas cng dengan variasi tekanan injeksi gas dan derajat waktu injeksi.Jurusan Teknik Mesin Institut Teknologi Sepuluh November. Surabaya.

Agus Budianto, Aguk Zuldi Fathallah, Semin. Analisa performa mesin diesel berbahan bakar batubara cair berbasis pada simulasi.Jurusan 
Teknik Sistem Perkapalan Institut Teknologi Sepuluh November. Surabaya.

Arismunandar.W(1994). Prisif kerja motor Bakar. Bandung ITB

Permana, Danu, (2005). Merawat \& Memperbaiki Mobil Diesel.Puspa Swara: Jakarta.

Febrian Wiilyanto, 1999, Peningkatan unjuk kerja motor diesel dengan penambahan pemanas solar, Universitas Kristen petra.

Drs. Boentaro, 2000, Mengatasi Kerusakan Mesin Diesel. Penerbit Puspa Swara.

http://www.budidarma.com

http://digilib.unila.ac.id

http://repository.unmuhpnk.ac.id

https://www.kitapunya.net

Kanzaki.co.jp 